\title{
Analisis Penurunan Parameter Limbah Cair Laundry Menggunakan Rotating Biological Contactor (Rbc)
}

\author{
Nurdwi Sartika ${ }^{1}$, Monik Kasman' ${ }^{1}$, Anggrika Riyanti ${ }^{*}$ \\ ${ }^{1}$ Program Studi Teknik Lingkungan Universitas Batanghari \\ Jalan Slamet Riyadi, Broni, Kota Jambi \\ *e-mail : anggrika.riyanti@unbari.ac.id
}

\begin{abstract}
Laundry waste water is a part of domestic liquid waste and its classified as grey water. Liquid waste from laundry business containing pollutants such as BOD, COD, TSS, Total Phosphate, and Methylene Blue Active Substance (MBAS) that can give negative impact to the environment if it is not treated first. The purpose in this study was to analyze the influence of detention time to eficiency of decreasing pollutant concentration by using Rotating Biological Contactor $(R B C)$ methods. The RBC used the palm fiber as the media. Variation of detention time in this study was 1, 3, 5, 7, 9, 11, 13, and 15 days. Linear regression was used to analysed the effect of detention time to pollutant concentration decreased. The result showed that the elimination efficiency of BOD, COD, TSS, Total phosphate and MBAS was $88 \%, 87 \%, 87 \%, 88 \%$ and $96 \%$. The regression analysis results showed that there was a significant relationship between detention time and efficiency of decreasing pollutant parameters concentration (BOD, COD, TSS, Total Phosphates) of laundry waste by using RBC, but has no significant relationship in MBAS parameter.
\end{abstract}

Keywords: Laundry waste; Rotating Biological Contactor (RBC); Regression analysis liniear.

\section{Pendahuluan}

Kegiatan usaha laundry di Indonesia semakin meningkat setiap tahunnya. Usaha ini memiliki manfaat besar bagi masyarakat, baik bagi penyedia maupun pengguna usaha laundry tersebut. Seiring bertambahnya kegiatan usaha ini maka perlu diikuti dengan pengelolaan guna mencegah terjadinya pencemaran akibat limbah yang dihasilkan.

Proses kerja dari usaha ini sangatlah konvensional yaitu mencampurkan air dengan deterjen sebagai bahan pencuci dikarenakan deterjen mempunyai sifat-sifat pembersih yang efektif dibandingkan dengan sabun biasa. Komponen terbesar dari deterjen yaitu bahan pembersih (surfaktan) berkisar $70-80 \%$ diikuti bahan builder (senyawa fosfat) berkisar $20-30 \%$, dan bahan aditif (pemutih dan pewangi) yaitu antara 2-8\% (Sawyer et al., 1978). Hampir semua usaha laundry membuang air limbah langsung ke badan air, seperti sungai, maupun selokan tanpa ada pengolahan terlebih dahulu. Tanpa disadari limbah cair laundry tersebut menyebabkan pencemaran air yang berakibat menurunnya kualitas perairan. Pencemaran tersebut dapat berakibat menurunnya daya dukung yang dimiliki oleh air. Oleh karena itu, diperlukan suatu teknologi untuk mengolah limbah laundry sebelum limbah itu dibuang ke badan air.

Salah satu alternatif pengolahan limbah cair laundry yang dapat digunakan adalah Rotating Biological Contactor (RBC). Rotating Biological Contactor (RBC) ialah suatu proses pengolahan limbah cair dengan menggunakan metode dimana unit pengolah air limbah ini berotasi dengan pusat sumbu/as yang digerakkan oleh motor drive system dan/atau tiupan udara (air drive system) dari difusser yang dibenam dalam air limbah, di bawah media berbahan plastik. Media tempat pelekatan mikroba dipasang sedemikian rupa sehingga terjadi kontak yang seluas-luasnya dengan air limbah dan oksigen yang terjadi silih berganti. Dimana metodenya melibatkan kontak dengan unsur-unsur biologi di dalam perputaran ataupun rotasi.

Berdasarkan penelitian Septiandinata (2017), kinerja sistem pengolahan limbah cair industri tahu menggunakan
Rotating Biological Contactor media ijuk ternyata dapat menurunkan konsentrasi polutan pencemar seperti BOD, COD, TSS dan minyak dan Lemak. Hasil uji menunjukkan efisiensi penyisihan BOD, COD, TSS, minyak dan lemak dengan waktu detensi optimum 18 jam secara berurutan sebesar $69 \%, 72 \%, 98 \%$, dan $85 \%$.

Oleh karena itu, penelitian ini dilakukan untuk mengetahui penurunan parameter pencemar pada limbah laundry menggunakan pengolahan biologi dengan Rotating Biological Contactor (RBC).

\section{Metodologi}

\subsection{Variabel Penelitian}

Penelitian bertujuan untuk mengamati penurunan konsentrasi pencemar dan pengaruh waktu detensi. Adapun variabel yang digunakan dalam penelitian ini.

1. Variabel bebas yaitu waktu detensi atau waktu kontak antara limbah cair usaha laundry dengan media RBC meliputi hari ke-1, hari ke-3, hari ke-5, hari ke -7, hari ke-9, hari ke-11, hari ke-13 dan hari ke-15.

2. Variabel terikat pada penelitian yaitu persentase penurunan konsentrasi polutan BOD, COD, TSS, Total fosfat, MBAS dan $\mathrm{pH}$.

Pengambilan sampel dilakukan pada hari ke-1, hari ke3, hari ke-5, hari ke-7, hari ke-9, hari ke-11, hari ke-13, hari ke-15 setiap pukul 07.00 dan 17.00 wib. Total sampel adalah 16 sampel.

Pengambilan sampel dalam penelitian ini yaitu :

1. Pada inlet (sebelum masuk) bak penampung unit rotating biological contactor $(\mathrm{RBC})$.

2. Pada outlet (setelah mengalami proses pengolahan) dengan rotating biological contactor (RBC).

\subsection{Tahap Experimen}

Pengolahan limbah cair usaha laundry dilakukan secara gravitasi ke rotating biological contactor, yaitu perputaran (rotasi) cakram ijuk untuk mengontakkan mikroorganisme/bakteri dengan oksigen bebas. Cakram 
diputar dengan sebuah motor listrik yang dihubungkan ke sebuah string belt yang sudah terpasang pada as cakram.

Adapun tahap-tahap dalam penelitian adalah sebagai berikut :

1. Pengambilan sampel awal air limbah dilakukan secara langsung pada pipa buangan limbah cair usaha laundry Aqualis.

2. Kemudian air limbah dimasukkan kedalam jerigen yang telah dipersiapkan sebagai wadah penyimpanan sementara.

3. Dilakukan pengujian awal terhadap kandungan parameter pencemar BOD, COD, TSS, Total fosfat, MBAS dan $\mathrm{pH}$ pada limbah usaha laundry Aqualis. Pengujian ini bertujuan untuk mengetahui berapa konsentrasi parameter pencemar yang terkandung pada limbah usaha laundry sebelum di lakukan pengolahan rotating biological contactor (RBC). Pengujian konsentrasi parameter pencemar ini dilakukan di Dinas Lingkungan Hidup

Provinsi Jambi.

4. Sampel air limbah laundry dimasukkan ke dalam rotating biological contactor (RBC) sebanyak 75 liter dengan kapasitas RBC 50 liter untuk menjaga kontinuitas air limbah pada RBC.

5. Selanjutnya dilakukan pengolahan limbah cair usaha laundry dengan menggunakan rotating biological contactor (RBC) selama 24 jam 15 hari

6. Pengambilan sampel air limbah laundry sebanyak 1,5 liter dilakukan sesuai waktu kontak yang telah dipilih, setelah itu air limbah ditambahkan secara kontinyu sebanyak 1,5 liter ke dalam reaktor rotating biological contactor (RBC) setiap hari ke- 1, hari ke- 3, hari ke-5, hari ke- 7, hari ke- 9, hari ke- 11, hari ke- 13, hari ke15 dengan waktu pengambilan sampel pada pukul 07.00 dan 17.00 WIB.

\section{Hasil dan Pembahasan}

\subsection{Karakteristik Limbah Cair Usaha Laundry}

Karakteristik limbah cair usaha laundry dilakukan untuk mengetahui kondisi limbah cair usaha laundry secara fisika dan kimia.Karakteristik limbah cair usaha laundry berpengaruh terhadap kemampuan alat dan metode pengolahan limbah cair usaha laundry.

Secara visual kondisi limbah cair usaha laundry dapat dilihat pada Gambar 1. Jika dilihat secara fisik, kondisi awal limbah cair usaha laundry, keruh, berbau, berwarna keabuabuan, dipermukaan limbah terdapat buih dan jika dibiarkan terdapat endapan dibagian dasar. Oleh karna itu perlu dilakukan pengolahan untuk efisiensi menurunkan kandungan pencemar limbah cair usaha laundry dengan menggunakan rotating biological contactor (RBC).

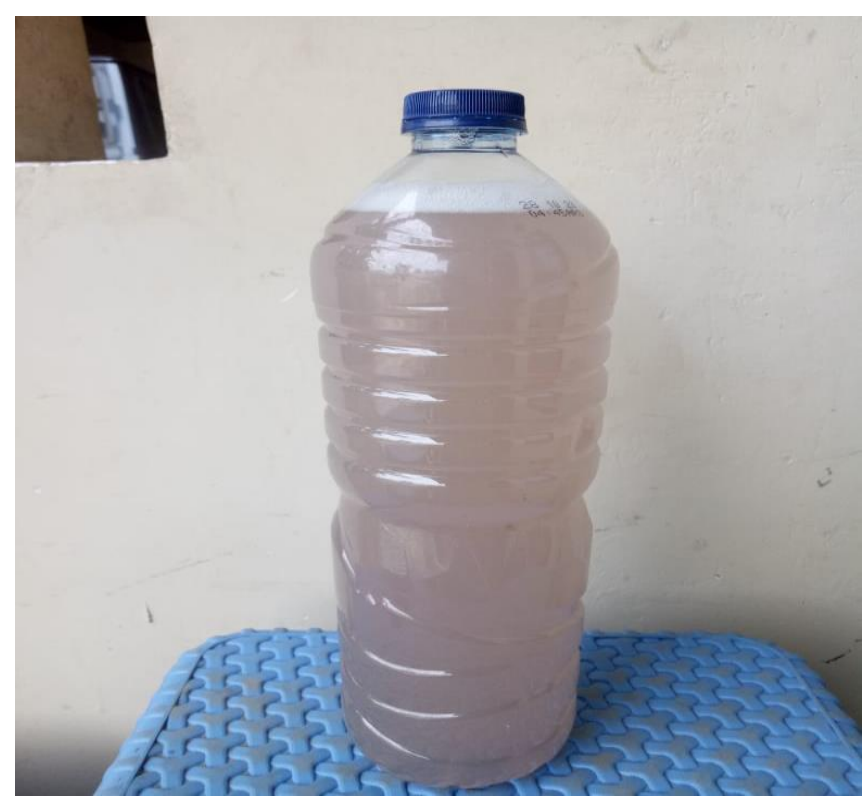

Gambar 1. Kondisi Air Baku Limbah Cair Usaha Laundry

\subsection{Analisis Pengaruh Waktu Detensi Terhadap Reduksi Parameter Pencemar}

\subsubsection{Pengaruh Waktu Detensi Terhadap Penurunan} Parameter BOD

BOD dianalisis untuk menghitung kebutuhan oksigen yang diperlukan oleh mikroorganisme untuk mengurai seluruh bahan organik yang terkandung dalam limbah cair usaha laundry. Parameter BOD limbah cair usaha laundry awal adalah $73 \mathrm{mg} / \mathrm{l}$. Pengambilan sampel dilakukan pada hari ke-1, hari ke-3, hari ke-5, hari ke-7, hari ke-9, hari ke-11, hari ke-13, dan hari ke-15 setiap pukul 07.00 dan 17.00 WIB. Setelah dilakukan pengolahan konsentrasi BOD mengalami penurunan.

Hasil pemeriksaan terhadap sampel limbah cair usaha laundry pada parameter BOD, konsentrasi yang tertinggi adalah $23 \mathrm{mg} / \mathrm{l}$, terendah sebesar $9 \mathrm{mg} / \mathrm{l}$. Dapat dikatakan bahwa limbah tersebut apabila dibuang ke lingkungan tidak mencemari lingkungan.

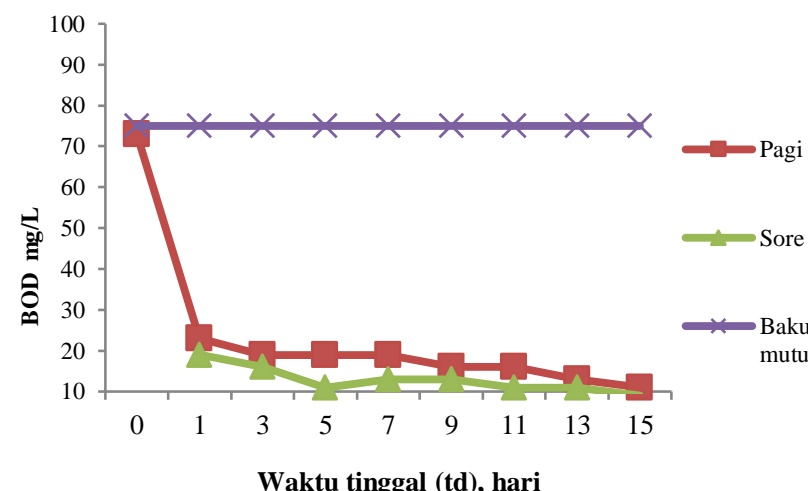

Gambar 2. Pengaruh Waktu Tinggal (td) terhadap Parameter BOD

Berdasarkan Gambar 2 diatas, pada pengamatan awal yaitu pada hari ke-1 (pagi), tampak bahwa presentasi penyisihan BOD terjadi penurunan secara signifikan yaitu sebesar $68 \%$ dan pada hari ke-1 (sore) terjadi penurunan yaitu sebesar $74 \%$. Pada pengamatan terakhir yaitu terjadi 
pada hari ke-15 (pagi), tampak bahwa terjadi penurunan yaitu sebesar $85 \%$ dan pada hari ke-15 (sore) terjadi penurunan yaitu sebesar $88 \%$. Terjadi naik turun pada hari ke-3, hari ke-5, hari ke-7, hari ke-9, hari ke-11 dan hari ke13, dikarenakan penambahan air limbah secara kontinyu ke dalam reaktor rotating biological contactor (RBC). Penurunan konsentrasi BOD dapat diindikasikan dengan besarnya senyawa organik yang terurai secara biologi. Hampir seluruh bakteri yang ada mampu menurunkan senyawa organik biodegradable ini.

Daya kerja alat pengolahan rotating biological contactor (RBC) limbah cair usaha laundry ini secara nyata sudah dapat menurunkan konsentrasi BOD sebesar $88 \%$. Penelitian ini lebih efektif bila dibandingkan dengan penelitiannya Septiandinata (2018), tentang pengolahan limbah industri tahu menggunakan rotating biological contactor (RBC) dapat menurunkan kandungan BOD sebesar $69 \%$.

\subsubsection{Pengaruh Waktu Detensi Terhadap Penurunan Parameter COD \\ COD merupakan jumlah oksigen yang dibutuhkan} untuk mengurai seluruh bahan organik yang terkandung dalam limbah cair usaha laundry. Parameter COD limbah cair usaha laundry awal adalah $162 \mathrm{mg} / \mathrm{l}$. Pengambilan sampel dilakukan pada hari ke-1, hari ke-3, hari ke-5, hari ke-7, hari ke-9, hari ke-11, hari ke-13, dan hari ke-15 setiap pukul 07.00 dan 17.00 WIB. Setelah dilakukan pengolahan konsentrasi COD mengalami penurunan.

Berdasarkan Gambar 3 diatas, pada pengamatan awal yaitu pada hari ke-1 (pagi), tampak bahwa presentasi penyisihan COD terjadi penurunan secara signifikan yaitu sebesar $70 \%$ dan pada hari ke-1 (sore) terjadi penurunan yaitu sebesar $74 \%$. Pada pengamatan terakhir yaitu terjadi pada hari ke-15 (pagi), tampak bahwa terjadi penurunan yaitu sebesar $85 \%$ dan pada hari ke-15 (sore) terjadi penurunan yaitu sebesar $87 \%$. Terjadi naik turun pada hari ke-3, hari ke-5, hari ke-7, hari ke-9, hari ke-11 dan hari ke13, dikarenakan penambahan air limbah secara kontinyu ke dalam reaktor rotating biological contactor (RBC). Penurunan ini disebabkan adanya kontak antara limbah terhadap biofilm, sehingga semakin lama waktu tinggal pengolahan limbah cair usaha laundry maka akan terjadi peningkatan suplai oksigen ke dalam air limbah dan juga mikroba lebih sering kontak dengan udara. Karena jumlah oksigen yang tersedia pada limbah meningkat maka jumlah mikroba pada media cakram semakin berkembang sehingga lapisan biofilm menjadi lebih banyak dan konsentrasi COD pada limbah akan mengalami penurunan (Ahmad, 2004).

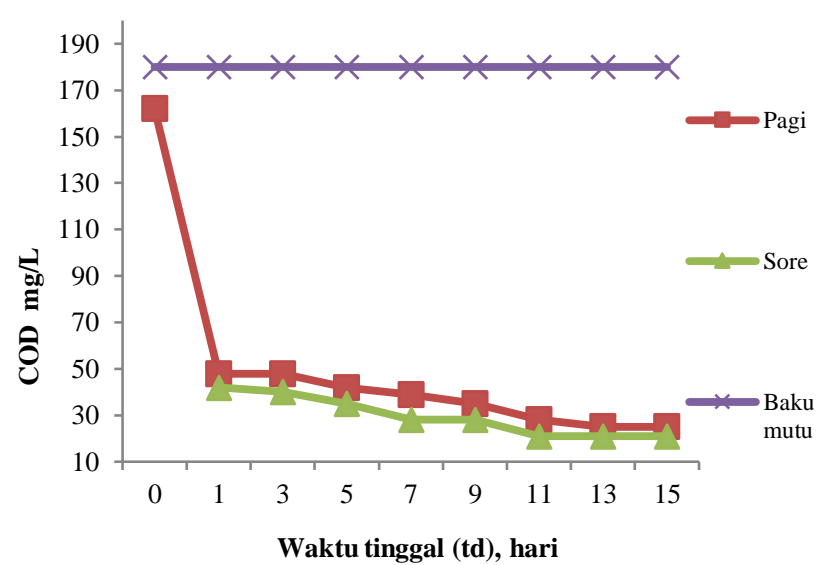

Gambar 3. Pengaruh Waktu Tinggal (td) terhadap Parameter COD

Daya kerja alat pengolahan rotating biological contactor (RBC) limbah cair usaha laundry ini secara nyata sudah dapat menurunkan konsentrasi COD sebesar 87 $\%$.Penelitian ini lebih efektif bila dibandingkan dengan penelitiannya Septiandinata (2018), tentang pengolahan limbah industri tahu menggunakan rotating biological contactor (RBC) dapat menurunkan kandungan COD sebesar $72 \%$.

\subsubsection{Pengaruh Waktu Detensi Terhadap Penurunan Parameter TSS \\ TSS dianalisis bertujuan untuk mengetahui tingkat} pencemaran air oleh padatan tersuspensi dalam limbah cair usaha laundry. Parameter TSS limbah cair usaha laundry awal adalah $68 \mathrm{mg} / \mathrm{l}$. Pengambilan sampel dilakukan pada hari ke-1, hari ke-3, hari ke-5, hari ke-7, hari ke-9, hari ke11, hari ke-13, dan hari ke-15 setiap pukul 07.00 dan 17.00 WIB. Setelah dilakukan pengolahan konsentrasi TSS mengalami penurunan.

Hasil pemeriksaan terhadap sampel limbah cair usaha laundry pada parameter TSS, konsentrasi yang tertinggi adalah $25 \mathrm{mg} / \mathrm{l}$, terendah sebesar $9 \mathrm{mg} / \mathrm{l}$. Dapat dikatakan bahwa limbah tersebut apabila dibuang ke lingkungan tidak mencemari lingkungan.

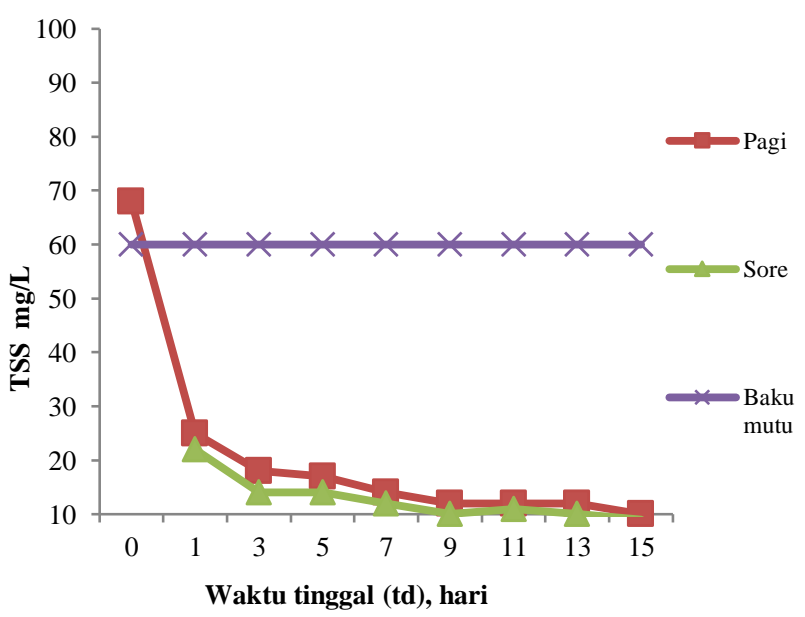

Gambar 4. Pengaruh Waktu Tinggal (td) terhadap Parameter TSS 
Berdasarkan Gambar 4 diatas, pada pengamatan awal yaitu pada hari ke-1 (pagi), tampak bahwa presentasi penyisihan TSS terjadi penurunan secara signifikan yaitu sebesar $63 \%$ dan pada hari ke-1 (sore) terjadi penurunan yaitu sebesar $68 \%$. Pada pengamatan terakhir yaitu terjadi pada hari ke-15 (pagi), tampak bahwa terjadi penurunan yaitu sebesar $85 \%$ dan pada hari ke-15 (sore) terjadi penurunan yaitu sebesar $87 \%$. Terjadi naik turun pada hari ke-3, hari ke-5, hari ke-7, hari ke-9, hari ke-11 dan hari ke13, dikarenakan penambahan air limbah secara kontinyu ke dalam reaktor rotating biological contactor (RBC).

Daya kerja alat pengolahan rotating biological contactor (RBC) limbah cair usaha laundry ini secara nyata sudah dapat menurunkan konsentrasi TSS sebesar $87 \%$. Penelitian ini kurang efektif bila dibandingkan dengan penelitiannya Septiadinata tentang pengolahan limbah industri tahu menggunakan rotating biological contactor (RBC) dapat menurunkan kandungan TSS sebesar $98 \%$.

\subsubsection{Pengaruh Waktu Detensi Terhadap Penurunan Parameter Total Fosfat}

Parameter Total Fosfat limbah cair usaha laundry awal adalah 0,806 . Pengambilan sampel dilakukan pada hari ke-1, hari ke-3, hari ke-5, hari ke-7, hari ke-9, hari ke-11, hari ke-13, dan hari ke-15 setiap pukul 07.00 dan 17.00 WIB. Setelah dilakukan pengolahan konsentrasi Total Fosfat mengalami penurunan.

Hasil pemeriksaan terhadap sampel limbah cair usaha laundry pada parameter Total Fosfat, konsentrasi yang tertinggi adalah 0,576 mg/l, terendah sebesar 0,098 mg/l. Dapat dikatakan bahwa limbah tersebut apabila dibuang ke lingkungan tidak mencemari lingkungan.

Berdasarkan Gambar 5 diatas, pada pengamatan awal yaitu pada hari ke-1 (pagi), tampak bahwa presentasi penyisihan Total Fosfat terjadi penurunan secara tidak signifikan yaitu sebesar $29 \%$ dan pada hari ke-1 (sore) terjadi penurunan yaitu sebesar $42 \%$. Pada pengamatan terakhir yaitu terjadi pada hari ke-15 (pagi), tampak bahwa terjadi penurunan yaitu sebesar $84 \%$ dan pada hari ke-15 (sore) terjadi penurunan yaitu sebesar $88 \%$. Penurunan Total Fosfat terjadi pada semua waktu detensi pagi atau sore hari.

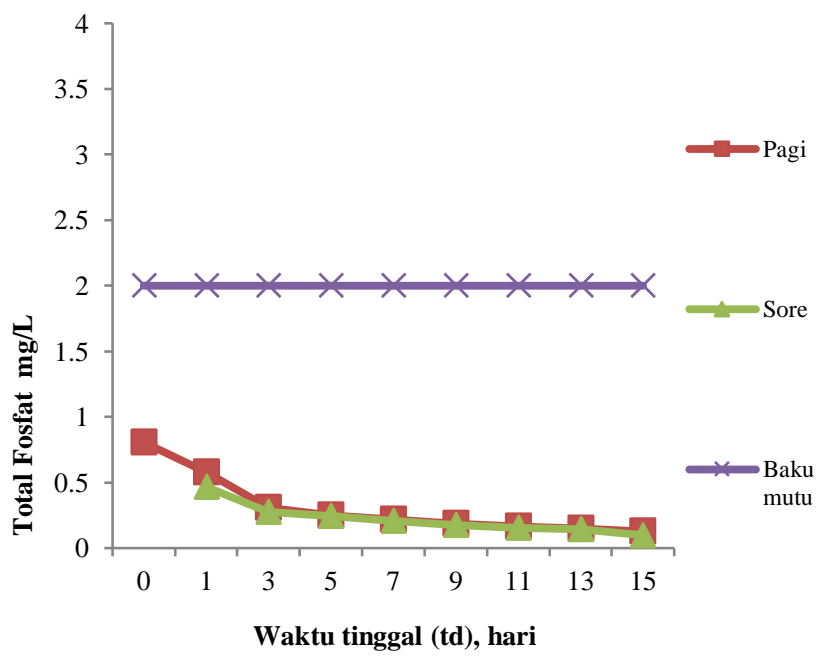

Gambar 5. Pengaruh Waktu Tinggal (td) terhadap Parameter Total Fosfat
Menurut teori, penurunan konsentrasi Total Fosfat dengan menggunakan cara biologi dengan memanfaatkan aktivitas mikroba dapat menurunkan konsentrasi fosfat di dalam air limbah. Rotating biological contactor (RBC) dengan biakan melekat adalah reaktor yang dilengkapi dengan media cakram (ijuk) sebagai tempat pertumbuhan mikroorganimse, yang merupakan reaktor pertumbuhan melekat. Fungsi media adalah sebagai tempat tumbuh dan berkembangnya mikroorganisme yang terlibat langsung dalam pengolahan air limbah. Mikroorganisme ini akan melapisi permukaan media membentuk lapisan massa yang tipis yang disebut biofilm.

Daya kerja alat pengolahan rotating biological contactor (RBC) limbah cair usaha laundry ini secara nyata sudah dapat menurunkan konsentrasi Total Fosfat sebesar $88 \%$.

\subsubsection{Pengaruh Waktu Detensi Terhadap Penurunan Parameter MBAS}

Parameter MBAS limbah cair usaha laundry awal adalah 1,56 mg/l. Pengambilan sampel dilakukan pada hari $\mathrm{ke}-1$, hari ke-3, hari ke-5, hari ke-7, hari ke-9, hari ke-11, hari ke-13, dan hari ke-15 setiap pukul 07.00 dan 17.00 WIB. Setelah dilakukan pengolahan konsentrasi MBAS mengalami penurunan.

Hasil pemeriksaan terhadap sampel limbah cair usaha laundry pada parameter MBAS, konsentrasi yang tertinggi adalah $0,215 \mathrm{mg} / \mathrm{l}$, terendah sebesar $0,067 \mathrm{mg} / \mathrm{l}$. Dapat dikatakan bahwa limbah tersebut apabila dibuang ke lingkungan tidak mencemari lingkungan.

Berdasarkan Gambar 6 diatas, pada pengamatan awal yaitu pada hari ke-1 (pagi), tampak bahwa presentasi penyisihan MBAS terjadi penurunan secara signifikan yaitu sebesar $86 \%$ dan pada hari ke-1 (sore) terjadi penurunan yaitu sebesar $88 \%$. Pada pengamatan terakhir yaitu terjadi pada hari ke-15 (pagi), tampak bahwa terjadi penurunan yaitu sebesar $95 \%$ dan pada hari ke-15 (sore) terjadi penurunan yaitu sebesar $96 \%$. Penurunan MBAS terjadi pada semua waktu detensi pagi atau sore hari.

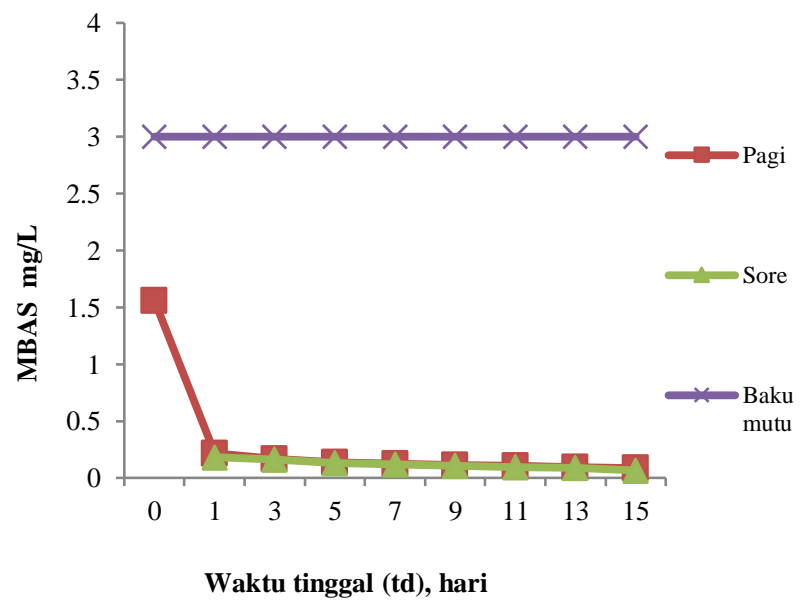

Gambar 6. Pengaruh Waktu Tinggal (td) terhadap Parameter MBAS

Hal ini terjadi karena adanya mikroorganisme yang terkandung di dalam media tumbuh dan mampu bertahan sehingga akhirnya dapat mendegradasi deterjen yang terkandung di dalam air (Titistiti, 2010). Mikroorganisme 
tumbuh pada putaran cakram (ijuk) mengoksidasi air limbah yang melewatinya. Sehingga air limbah yang keluar dari hasil pengolahan aman untuk dibuang ke lingkungan. Daya kerja alat pengolahan rotating biological contactor (RBC) limbah cair usaha laundry ini secara nyata sudah dapat menurunkan konsentrasi MBAS sebesar $96 \%$.

\subsubsection{Analisis Regresi Liniear Pengaruh Waktu Detensi Terhadap Parameter Pencemar \\ Hasil analisis regresi linear ditampilkan pada Tabee} 1 berikut.

Tabel 1. Hasil Analisis Regresi Antara Waktu Detensi terhadap Penurunan Konsentrasi Parameter Pencemar

\begin{tabular}{ccccc}
\hline Parameter & $\mathrm{R}$ & $\mathrm{R}^{2}$ & $\mathrm{Sig}$ & Persamaan Regresi \\
\hline BOD & 0,792 & 0,627 & 0,011 & $\mathrm{y}=25,675-1,173 \mathrm{x}$ \\
COD & 0,843 & 0,712 & 0,004 & $\mathrm{y}=59,197-2,871 \mathrm{x}$ \\
TSS & 0,833 & 0,695 & 0,005 & $\mathrm{y}=24,968-1,246 \mathrm{x}$ \\
Total Fosfat & 0,897 & 0,806 & 0,001 & $\mathrm{y}=0,413-0,023 \mathrm{x}$ \\
MBAS & 0,638 & 0,407 & 0,064 & $\mathrm{y}=0,387-0,026 \mathrm{x}$ \\
\hline
\end{tabular}

Hasil analisis regresi yang ditampilkan pada Tabel 1 menunjukkan bahwa lama waktu detensi mempunyai pengaruh yang kuat terhadap penurunan konsentrasi BOD dan MBAS, yang ditunjukkan dengan nilai R sebesar 0,792 dan 0,638. Pengaruh lama waktu detensi pada parameter COD, TSS dan total fosfat (nilai R) berada lebih dari 0,80 mendekati 1 yang artinya kedua variabel mempunyai hubungan yang sangat kuat.

Sementara untuk nilai $\mathrm{R}^{2}$ ( $R$ square) pada Tabel 1 menunjukkan bahwa lama waktu detensi berpengaruh sebesar $62,7 \%$ terhadap penurunan BOD, 71,2\% terhadap penurunan COD, 69,5\% terhadap penurunan TSS, $80,6 \%$ terhadap penurunan total fosfat dan $40,7 \%$ terhadap penurunan MBAS.

Hasil analisis regresi pada parameter BOD, COD, TSS dan total fosfat menunjukkan nilai signifikansi yang lebih kecil dari tingkat signifikansi yang digunakan yaitu $\alpha$ $=5 \%(0,05)$, yang berarti lama waktu detensi mempunyai pengaruh yang signifikan terhadap penurunan BOD, COD, TSS dan total fosfat. Sedangkan nilai signifikansi parameter MBAS adalah 0,064 >0,05. Hal ini menunjukkan bahwa persamaan regresi tidak memenuhi kriteria linieritas yang artinya lama waktu detensi tidak mempunyai pengaruh yang signifikan terhadap penurunan MBAS

\section{Kesimpulan}

Kesimpulan pada penelitian ini sebagai berikut :

1. Pengolahan limbah cair usaha laundry menggunakan Rotating Biological Contactor (RBC) media ijuk ternyata dapat menurunkan konsentrasi polutan pencemar seperti BOD, COD, TSS, Total Fosfat dan MBAS. Hasil uji menunjukkan efisiensi penyisihan BOD, COD, TSS, Total Fosfat dan MBAS dengan waktu detensi optimum 15 hari secara berurutan sebesar $88 \%, 87 \%, 87 \%, 88 \%$ dan $96 \%$.

2. Hasil analisis regresi linear menunjukkan bahwa lama waktu detensi mempunyai pengaruh yang kuat dan signifikan terhadap penurunan BOD, COD, TSS dan total fosfat. Namun tidak mempunyai pengaruh yang signifikan terhadap penurunan MBAS.

\section{Daftar Pustaka}

Fachrurozi, M., Listiati B.M., Dyah S. 2010.Pengaruh Variasi Biomassa Pistia Stratiotes L. Terhadap Penurunan Kadar BOD, COD, dan TSS Limbah Cair Tahu Di Dusun Klero Sleman Yogyakarta. Jurnal Kesehatan Masyrakat, 4(1) : 1-75.

Ghiovani, D. 2017. Fitoremediasi Air yang Tercemar Limbah Laundry dengan Menggunakan Kayu Apu (Pistia Stratiotes). Jurnal Teknik ITS, 6 (2).

Ginting, P. 2007. Sistem Pengolahan Lingkungan dan Limbah Industri. Bandung: Yrama Widya.

Kubare, M. Dan Haarhoff, J. 2010. Rational Design Of Domestic Biosand Filters. Journal Of Water Supply: Research And Technology.

Padmanabha dan Purnama. 2015. Efektivitas Model InstalasiPengolahan Air Limbah Vertical Flow SubSurface Flow Constructed Wetland dalam Mengolah Air Limbah Kegiatan Laundry di Kabupaten Bandung. PS Ilmu Kesehatan Masyarakat. Fakultas Kedokteran. Universitas Udayana.

Pemerintah Republik Indonesia. 2001. Peraturan Pemerintah Nomor 82 tahun 2001 Tentang Pengelolaan Kualitas Air dan Pengendalian Pencemaran Air. Jakarta.

Peraturan Menteri Lingkungan Hidup No. 5 Tahun 2014 tentang Baku Mutu Air Limbah. Jakarta.

Puspita, D. 2008. Penurunan Konsentrasi Total Suspended Solid (TSS) Pada Limbah Laundry dengan Reaktor Activated Carbon. Yogyakarta : Program Studi Sarjana Fakultas Teknik Sipil dan Perencanaan Jurusan Teknik Lingkungan Universitas Islam Indonesia.

Rosnelly, C.M. 2010. Pengaruh Rasio Anhidrida Asetat dalam Proses Asetilasi Selulosa Pulp Kayu Sengon (Paraserianthes falcataria) dalam Pembuatan Polimer Selulosa Triasetat. Vol.27 No.1 Juni 2010, pp 1-11. Bogor: Teknologi Industri Pertanian-Fateta IPB.

Sawyer, C.N. and McCarty, P. L., 1978. Chemistry for Environmental Engineering.Third edition. McGrawHill Book Company, Tokyo.532p.

Sayekti, Rini, Riyanto Haribowo, Yohana Vivit dan Agung Prabowo. 2012. Studi Efektivitas Penurunan Kadar BOD, COD dan NH3 pada Limbah Cair Rumah Sakit Dengan Rotating Biological Contactor. Jurusan Teknik Pengairan Fakultas Teknik, Universitas Brawijaya, Malang.

Septiandinata, J. 2017. Analisis Penurunan Konsentrasi Limbah Cair Industri Tahu Menggunakan Rotating Biological Contactor. Skripsi. Jambi : Universitas Batanghari.

Silalahi, U. 2010. Metode Penelitian Sosial. Jakarta: Refika Aditama.

Undang-Undang Nomor 32 Tahun 2009 tentang Perlindungan dan Pengelolaan Lingkungan Hidup. Jakarta: Sekretariat Negara. 